\title{
Schwanoma Vulvar
}

\section{Yasmina José Gutiérrez ${ }^{1,2 *}$, Leyre Ruiz Campo ${ }^{3}$, Elena Lázaro García ${ }^{1}$, Raúl Bolea Tobajas Miguel Ángel Ruiz Conde ${ }^{1,2}$}

\author{
${ }^{1}$ Department of Gynecology, Miguel Servet University Hospital, College of Medicine, Zaragoza, Spain \\ ${ }^{2}$ IACS, Aragon Institute of Health Sciences, Zaragoza, Spain \\ ${ }^{3}$ Department of Obstetrics and Gynecology, San Jorge Hospital, Huesca, Spain \\ Email: ${ }^{*}$ yjosegu@hotmail.com
}

How to cite this paper: Gutiérrez, Y.J. Campo, L.R., García, E.L., Tobajas, R.B. and Conde, M.Á.R. (2017) Schwanoma Vulvar. Open Access Library Journal, 4: e3102. https://doi.org/10.4236/oalib.1103102

Received: January 9, 2017

Accepted: March 11, 2017

Published: March 14, 2017

Copyright $\odot 2017$ by authors and Open Access Library Inc.

This work is licensed under the Creative Commons Attribution International License (CC BY 4.0).

http://creativecommons.org/licenses/by/4.0/

\begin{abstract}
Schwannoma, also known as neurinoma or neurilemmoma, is a benign tumor that arises from the Schwann cells of the nerve sheath. This neoplasm often affects peripheral nerves although it may occur in soft tissues. Vulval location is extremely rare. We relate the case report of a 45 -year-old woman with history of vulval mass excised in 2012 and diagnosed as benign schwannoma. She currently presents with local recurrence.
\end{abstract}

\section{Subject Areas}

Oncology

\section{Keywords}

Schwannoma, S100 Proteins, Vulva

\section{Introduction}

Schwannoma is a benign tumor that arises from the neural sheath Schwann cells of the peripheral nerves. It is generally a solitary, well circumscribed and encapsulated tumor. The most common locations are the head, neck, upper and lower extremities, posterior mediastinum and retroperitoneum [1]. It rarely affects the female genitalia. Thus, in the vulvar region, epithelial tumors are the most common, and mesenchymal tumors comprise less than $10 \%$ of them [2].

In case of a suspicious vulvar tumor, taking a biopsy is required to histopathological examination and to exclude malignancy. Immunohistochemistry studies are of great value in differential diagnosis among these conditions [3].

According to our best knowledge, only a few cases of vulvar schwannoma have been reported in the literature [4]. In this study, we report a case of a 45-year-old woman with a schwannoma arising in the left labium majus. After 
the initial complete excision the tumor recurred.

\section{Case Report}

A 45-year-old Spanish woman, gravida 2, para 1, and with a previous history of a cesarean section, was referred to our hospital in 2012 for evaluation of a mass in her left labium majus. The size measured $4 \times 3 \mathrm{~cm}$. In March 2012 surgical excision with clear margins was performed. The anatomopathological result revealed a benign schwannoma of the vulva, with clear margins confirmed. The patient was not controlled at our hospital because of changing in address. In April 2014 she was referred again for the study of a new vulvar mass, 4 to $5 \mathrm{~cm}$ in size, and placed in the previous excision area.

Magnetic Resonance Imaging (MRI) with contrast material showed a soft tissue mass (signal intensity similar to that of muscle) affecting the lower third and part of the middle third of the vagina, measuring $4 \times 3 \times 3 \mathrm{~cm}$. The mass was starting to invade left paravaginal fat tissue. It was irregularly shaped and showed locally aggressive behavior. Also, it demonstrated avid homogeneous contrast enhancement. There were no pathological findings in the upper third of the vagina, cervix, uterus, adnexa or rectum. Left labium majus biopsy in the lesion area reported a local recurrence of vulvar schwannoma.

Pre-operatory study was completed with laboratory studies and chest radiograph. There were no other relevant findings.

15th April 2014 surgical excision of the vulvar mass was performed and completed with a re-excision of the internal border towards vagina. Findings described were a non-tender mass located in inferior third of left labium majus, 5 $\mathrm{cm}$ in size, very close to rectovaginal septum, and without apparent invasion of vagina or rectum. There was no inguinal lymphadenopathy.

Figure 1 shows the vulvar tumor resection and Figure 2 the vulva after tumor resection. Figure 3 shows vulvar suture and Figure 4 the tumor prepared to submit pathological anatomy. The postoperative evolution was favorable.

Definitive anatomopathological report described a benign mesenchymal

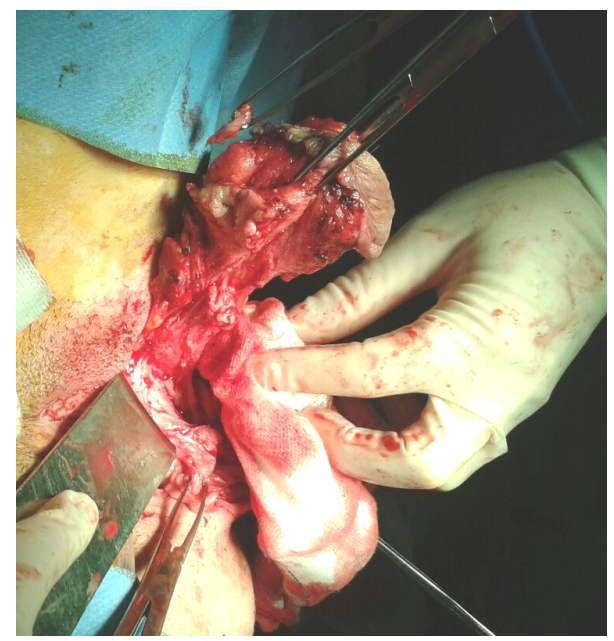

Figure 1. Vulvar tumor resection. 


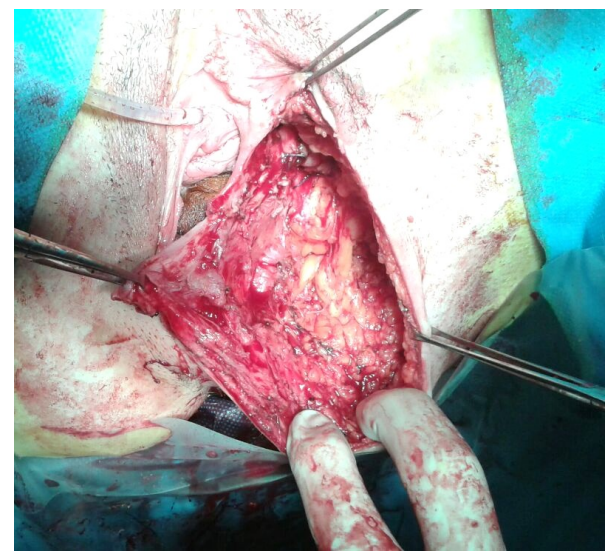

Figure 2. Vulva after tumor resection.

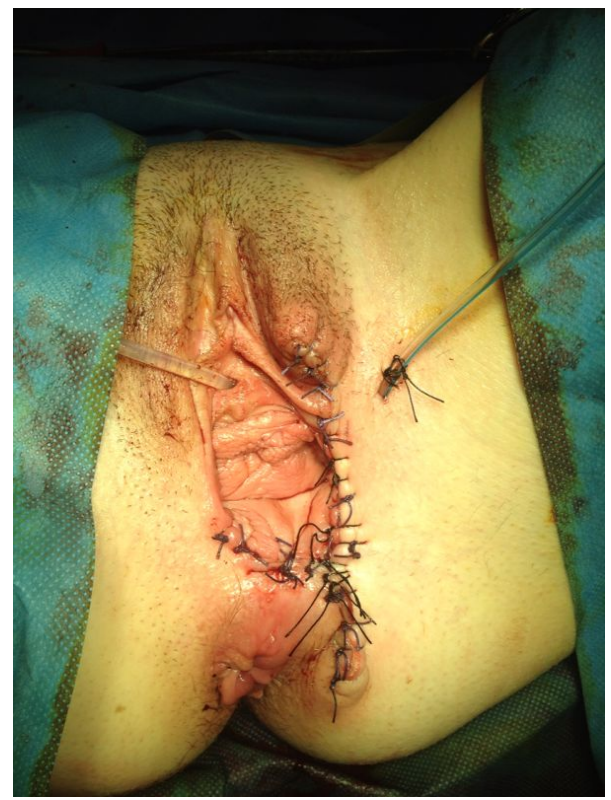

Figure 3. Vulvar suture.

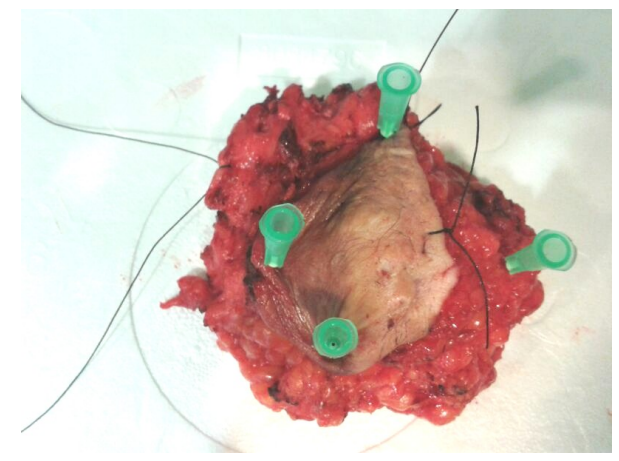

Figure 4. Tumor prepared to submit pathological anatomy.

tumor that originates from nerve sheath, with an infiltrative growth pattern, according to a diffuse neurofibroma. It measured $4.5 \mathrm{~cm}$ in its craniocaudal extension and the maximum anteroposterior diameter was $2.3 \mathrm{~cm}$. The lesion appeared 
to be separating and infiltrating normal skeletal muscle fibers and margins were informed as positive. Immunohistochemistry studies demonstrated neoplastic cells strongly positive for S100 protein and vimentin and negative for desmin; Ki-67 index was $1 \%$ - 3\%; positive estrogen and progesterone receptors; positive $\mathrm{CD}-34$; positive type IV collagen and negative neurofilament protein. Figure 5 shows hematoxilyn eosin, note elongated nuclei with a wavy, serpentine configuration and pointed ends, infiltrating muscle and Figure 6 like there are immunoreactive for $\mathrm{S} 100$ protein.

The re-excision specimen was described as fragments of squamous mucosa with focal invasion by diffuse neurofibroma. Margins were also positive.

The case was presented to the Gynecologic Oncology Committee and decided periodic monitoring of the patient.

\section{Discussion}

Schwannoma is a benign tumor that arises from the well differentiated Schwann cells of the nerves heath. Malignant progression is extremely rare [5]. It occurs most commonly in the age group of 20 - 50, although it has been described from 5 to 84 years [4]. There are no differences between genders. The patient described here belongs to the most frequent age range.

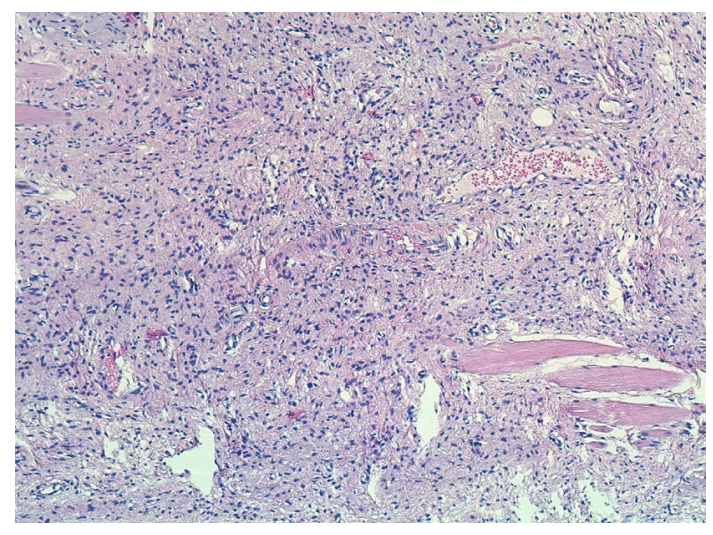

Figure 5. Hematoxilyn eosin, note elongated nuclei with a wavy, serpentine configuration and pointed ends, infiltrating muscle.

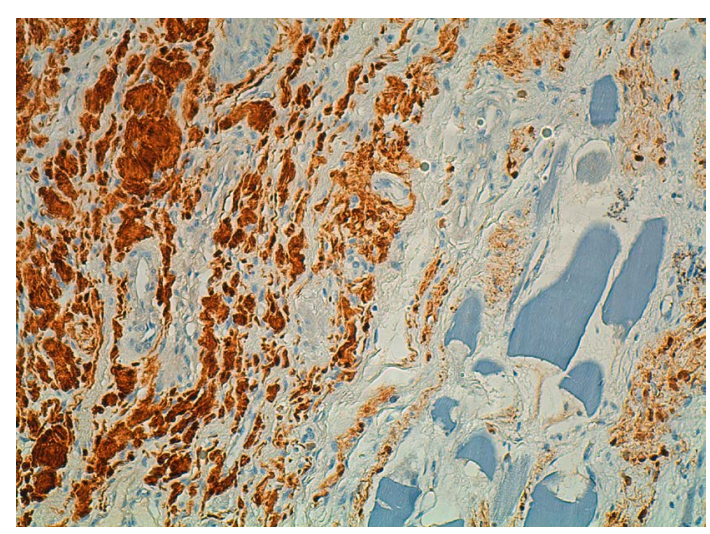

Figure 6. There are immunoreactive for $\mathrm{S} 100$ protein. 
The most common locations are the head, neck, flexor surface of upper and lower extremities, spinal cervical roots, ulnar nerve and, less commonly but described, posterior mediastinum and retroperitoneum [6] [7] [8] [9] [10]. It rarely affects the female genitalia. To date, only 18 cases, including ours, of vulvar schwannoma have been reported in the literature from 1983 to 2014 [3]-[15].

It is generally a solitary slow-growing tumor [3]. The importance of clinical findings for differential diagnosis with malignant diseases is remarkable.

On the treatment side, surgical excision has been radically curative in a case of benign schwannoma and the prognosis is excellent. Recurrence has been detected in few patients following incomplete removal. Clear resection margins are important in the prevention of recurrence, although this can be difficult depending on the location of the tumor, especially when structures like urethra or rectum are next to the surgical area.

The only report vulvar neurilemmoma recurred, beside our case, was a patient with the plexiform type who recurred twice, and was alive and well three years after the second resection [9].

Immunohistochemically malign schwannomas are thought to be composed of dedifferentiated schwann cells that had somewhat lost their capacity to synthesise S-100 protein [3]. In our case, most of the schwann cells were strongly positive for S-100 protein. This method supported that the lesion is a benign nature. The conventional type of neurilemmoma is the most common type in the vulvar area, reported in eleven of the eighteen cases in the literature between 1983 and 2014. There was five cases reported of plexiform variants despite is one of the least common histologic variants [9] [13] [15].

The size of vulvar neurilemmoma ranged from $0.6 \mathrm{~cm}$ up to $15 \mathrm{~cm}$ with mean: $4.3 \mathrm{~cm}$ [3]-[15], in our patient de size reported in the anatomopathologyc study was $4.5 \times 2.3 \mathrm{~cm}$, and it was located in the labium where are located most of the vulvar neurilemmomas.

Although rare, neurilemmoma should be considered in the differential diagnosis of vulvar masses, we should be aware that schwannoma can occur in the vulva.

\section{Acknowledgements}

This work was supported by the IACS, the Aragon Institute of Health Sciences, Source of FEDER co-financing.

\section{Conflicts of Interest}

The authors have no conflicts of interest relevant to this article.

\section{References}

[1] Weiss, S.W. and Goldblum, J.R. (2001) Enzinger and Weiss's Soft Tissue Tumors. 4th Edition, Mosby Inc., St Louis.

[2] Elder, D.E., Elenitsas, R., Johnson, B.L. and Murphy, G.F. (2005) Lever's Histopahology of Skin. Lippincott Williams \& Wilkins, Philadelphia. 
[3] Bozkurt, M. and Kara, D. (2013) Giant Vulvar Schwannoma: A Case Report. Acta Medica Iranica, 51, 427-429.

[4] Kim, N., Cho, H. and Lee, S. (2011) Vulvar Neurilemmoma at the Labium Minus. Korean Journal of Obstetrics \& Gynecology, 54, 326-329. https://doi.org/10.5468/KJOG.2011.54.6.326

[5] Fong, K.L., Bouwer, H., Baranyai, J. and Jones, R.W. (2009) Ancient Schwannoma of the Vulva. Obstetrics \& Gynecology, 113, 510-512. https://doi.org/10.1097/AOG.0b013e318188042f

[6] Cárdenas, L.F. and Sangüeza, O. (2009) Schwannoma con cambios degenerativos, schwannoma anciano. Revista de la Asociación Colombiana de Dermatología, 17, 236-238.

[7] Ferrara, N., Di Marino, M., Rossiello, L. and Baldi, A. (2003) Wagner-Meissner Neurilemmoma of the Vulva. International Journal of Dermatology, 42, 550-551. https://doi.org/10.1046/j.1365-4362.2003.01756_1.x

[8] Huang, H.J., Yamabe, T. and Tagawa, H. (1983) A Solitary Neurilemmoma of the Clitoris. Gynecologic Oncology, 15, 103-110.

https://doi.org/10.1016/0090-8258(83)90122-1

[9] Woodruff, J.M., Marshall, M.L., Godwin, T.A., Funkhouser, J.W., Thompson, N.J. and Erlandson, R.A. (1983) Plexiform (Multinodular) Schwannoma. A Tumor Simulating the Plexiform Neurofi Broma. American Journal of Surgical Pathology, 7, 691-697. https://doi.org/10.1097/00000478-198310000-00009

[10] Yamashita, Y., Yamada, T., Ueki, K., Ueki, M. and Sugimoto, O. (1996) A Case of Vulvar Schwannoma. Journal of Obstetrics and Gynaecology Research, 22, 31-34. https://doi.org/10.1111/j.1447-0756.1996.tb00932.x

[11] Hanafy, A., Lee, R.M. and Peterson, C.M. (1997) Schwannoma Presenting as a Bartholin's Gland Abscess. Australian and New Zealand Journal of Obstetrics and Gynaecology, 37, 483-484. https://doi.org/10.1111/j.1479-828X.1997.tb02469.x

[12] Quesada, G., Solera, J.C., Sanchez-Baartolome, J., Vazquez, F. and Lopez-Garcia, L. (1998) Benign Schwannoma of the Vulva: A Case Report. Journal of Gynecologic Surgery, 14, 195-198. https://doi.org/10.1089/gyn.1998.14.195

[13] Santos, L.D., Currie, B.G. and Killingsworth, M.C. (2001) Case Report: Plexiform Schwannoma of the Vulva. Pathology, 33, 526-531. https://doi.org/10.1080/00313020120083313

[14] Fujimoto, E., Onishi, Y., Tajima, S. and Okura, T. (2004) Vulvar Schwannoma. Rinsho Derma, 46, 548-549.

[15] Agaram, N.P., Prakash, S. and Antonescu, C.R. (2005) Deep-Seated Plexiform Schwannoma: A Pathologic Study of 16 Cases and Comparative Analysis with the Superficial Variety. American Journal of Surgical Pathology, 29, 1042-1048. 
Submit or recommend next manuscript to OALib Journal and we will provide best service for you:

- Publication frequency: Monthly

- 9 subject areas of science, technology and medicine

- Fair and rigorous peer-review system

- Fast publication process

- Article promotion in various social networking sites (LinkedIn, Facebook, Twitter, etc.)

- Maximum dissemination of your research work

Submit Your Paper Online: Click Here to Submit

Or Contact service@oalib.com 